\title{
The Role of Dexmedetomidine Sedation on Flexible Fiberoptic Bronchoscopy Procedure
}

\author{
Fazli Yanik* \\ Deparment of Thoracic Surgery, Trakya University, Turkey
}

Submission: May 07, 2018; Published: May 11, 2018

*Corresponding author: Fazli Yanik, Deparment Thoracic Surgery, Trakya University, Gogus Cerrahi Ad, Kat: 4, 22000, Edirne, Turkey, Tel: +902842355936; Fax: +902842355936; Email: fazliyanik@hotmail.com

\begin{abstract}
Flexible fiberoptic bronchoscopy (FOB) is an invasive method that is frequently used in the diagnosis, staging and treatment of lung diseases. The complaints of coughing, swallowing, feeling of breathlessness and pain that occur during FOB operation applied in the presence of local anesthesia frequently occur. Performing of the FOB procedure in conjunction with local anesthesia in the presence of sedation is preferred in order to minimize the existing problems. Dexmedetomidine is a new sedo-analgesic agent which a candidate for alternative to the commonly used midazolam-propofol or midazolam-opioid combinations and has analgesic, sedative, anxiolytic properties. At appropriate intravenous, intranasal, or sublingual doses, it may provide sedoanalgesia without respiratory depression. The ability to use without anesthesiologist, analgesia, sedation, anxiolytic and amnesic properties are superior to other sedo-analgesic drugs. Nevertheless, there is a need for multicentre randomized controlled studies for the role of sedo-analgesia with dexmedetomidine
\end{abstract}

\section{The Role of Dexmedetomidine Sedation on Flexible} Fiberoptic Bronchoscopy Procedure

Flexible fiberoptic bronchoscopy (FOB) is an invasive method that is frequently used in the diagnosis, staging and treatment of lung diseases. The complaints of coughing, swallowing, feeling of breathlessness and pain that occur during FOB operation applied in the presence of local anesthesia frequently occur. This makes it difficult to apply the procedure in terms of both the patient and the physician. In this respect, application of the FOB procedure in conjunction with local anesthesia in the presence of sedation is preferred in order to minimize the existing problems. However, additional problems of sedative agents can be detected. Anesthetic agents used for sedation may cause pathologies such as respiratory depression, hypoxia, arrhythmia and myocardial ischemia. The ideal sedative agent to be used for FOB operation is that it does not increase hypoxia and cause hemodynamic changes or minimal changes that can be tolerated. Dexmedetomidine hydrochloride; is a specific alpha-2 receptor agonist in the imidazolines subgroup that is administered to the market to be used in the intensive care setting for continuous intravenous sedation. Although it was originally intended for the sedation of ICU patients, it is also used increasingly in non-operating sedo-analgesia $[1,2]$. It is a new sedo-analgesic agent which a candidate for alternative to the commonly used midazolam-propofol or midazolamopioid combinations and has analgesic, sedative, anxiolytic properties. Transmucosal absorption is also high. The locus acts through the receptors on the spleen and provides sedation and analgesia through receptors on the spinal cord without respiratory depression. Effects of respiratory depression more effectiveness of other sedative agents, such as propofol and midazolam. However, it has negative effects such as hypotension and bradycardia [1-3]. Before FOB, nasal 2\% lidocaine is sprayed to provide local anesthesia at nasopharyngeal, orafrenx and vocal cord level. Subsequently, dexmedetomidine is used with intravenous, intranasal or sublingual dose of 1 microgram $/ \mathrm{kg}$ is sufficient for sedation and pain. Dexmedetomidine should be given approximately 20 minutes before the procedure. The duration of the effect is 30-45 minutes [3]. Although it is used more frequently in other endoscopic procedures, studies in the literature on the use of dexmedetomidine for sedation for awake FOB are very rare. It has been reported to prevent myocardial ischemia due to less hypotension, absence of respiratory depression and good analgesia [4]. The ability to use without anesthesiologist, analgesia, sedation, anxiolytic and amnesic properties are superior to other sedo-analgesic drugs.

\section{Conclusion}

In conclusion, in performing FOB, dexmedetomidine may be a good alternative to midazolam/opioid combination with low side effect profile. The intranasal and sublingual 
applicability of the medicine can provide advantages in everyday practice. Nevertheless, there is a need for multicentre randomized controlled studies for the role of sedoanalgesia with dexmedetomidine while performing FOB.

\section{References}

1. Hoflten T, Baykara N , Arslan Z , Solak M , Toker K, Ilgaz A (2009) Comparison of Deksmedetomidin and Propofol Effects During Flexible Fiberoptic Bronchoscopy Solunum 11(3): 115-120.

This work is licensed under Creative Commons Attribution 4.0 License DOI: 10.19080/IJOPRS.2018.03.555610
2. Kar Kurt O, Talay F, Kargı A, Yasar Z, Tug T (2015) Sedation for fiberoptic bronchoscopy: review of the literature Tuberk Toraks 63(1): 42-47.

3. Liao W, Ma G, Su QG, Fang Y, Gu BC, et al. (2012) Dexmedetomidine versus midazolam for conscious sedation in postoperative patients undergoing flexible bronchoscopy: a randomized study. J Int Med Res 40(4): 1371-1380.

4. Arain SR, Ebert TJ (2002) The efficacy, side effects, and recovery characteristics of dexmedetomidine versus propofol when used for intraoperative sedation. Anesth Analg 95(2): 461-466.

\section{Your next submission with Juniper Publishers} will reach you the below assets

- Quality Editorial service

- Swift Peer Review

- Reprints availability

- E-prints Service

- Manuscript Podcast for convenient understanding

- Global attainment for your research

- Manuscript accessibility in different formats

( Pdf, E-pub, Full Text, Audio)

- Unceasing customer service

Track the below URL for one-step submission https://juniperpublishers.com/online-submission.php 